\title{
Radiocarbon analysis in an Alpine ice core: record of anthropogenic and biogenic contributions to carbonaceous aerosols in the past (1650-1940)
}

\author{
T. M. Jenk ${ }^{1,2}$, S. Szidat ${ }^{1,2}$, M. Schwikowski ${ }^{2}$, H. W. Gäggeler ${ }^{1,2}$, S. Brütsch ${ }^{2}$, L. Wacker $^{3}$, H.-A. Synal ${ }^{4}$, and M. Saurer ${ }^{2}$ \\ ${ }^{1}$ Department of Chemistry and Biochemistry, University of Bern, Bern, Switzerland \\ ${ }^{2}$ Paul Scherrer Institut, Villigen PSI, Switzerland \\ ${ }^{3}$ Institute for Particle Physics, ETH Hönggerberg, Zürich, Switzerland \\ ${ }^{4}$ Paul Scherrer Institut, c/o Institute for Particle Physics, ETH Hönggerberg, Zürich, Switzerland
}

Received: 29 May 2006 - Published in Atmos. Chem. Phys. Discuss.: 7 July 2006

Revised: 30 October 2006 - Accepted: 20 November 2006 - Published: 29 November 2006

\begin{abstract}
Long-term concentration records of carbonaceous particles (CP) are of increasing interest in climate research due to their not yet completely understood effects on climate. Nevertheless, only poor data on their concentrations and sources before the 20th century are available. We present a first long-term record of organic carbon (OC) and elemental carbon (EC) concentrations - the two main fractions of $\mathrm{CP}$ - along with the corresponding fraction of modern carbon $\left(\mathrm{f}_{M}\right)$ derived from radiocarbon $\left({ }^{14} \mathrm{C}\right)$ analysis in ice. This allows a distinction and quantification of natural (biogenic) and anthropogenic (fossil) sources in the past. CP were extracted from an ice archive, with resulting carbon quantities in the microgram range. Analysis of ${ }^{14} \mathrm{C}$ by accelerator mass spectrometry (AMS) was therefore highly demanding. We analysed 33 samples of 0.4 to $1 \mathrm{~kg}$ ice from a $150.5 \mathrm{~m}$ long ice core retrieved at Fiescherhorn glacier in December 2002 $\left(46^{\circ} 33^{\prime} 3.2^{\prime \prime} \mathrm{N}, 08^{\circ} 04^{\prime} 0.4^{\prime \prime} \mathrm{E} ; 3900 \mathrm{~m}\right.$ a.s.1.). Samples were taken from bedrock up to the firn/ice transition, covering the time period 1650-1940 and thus the transition from the preindustrial to the industrial era. Before $\sim 1850$, OC was approaching a purely biogenic origin with a mean concentration of $24 \mu \mathrm{g} \mathrm{kg}^{-1}$ and a standard deviation of $7 \mu \mathrm{g} \mathrm{kg}^{-1}$. In 1940, OC concentration was about a factor of 3 higher than this biogenic background, almost half of it originating from anthropogenic sources, i.e. from combustion of fossil fuels. The biogenic EC concentration was nearly constant over the examined time period with $6 \mu \mathrm{g} \mathrm{kg}^{-1}$ and a standard deviation of $1 \mu \mathrm{g} \mathrm{kg}^{-1}$. In 1940, the additional anthropogenic input of atmospheric EC was about $50 \mu \mathrm{g} \mathrm{kg}^{-1}$.
\end{abstract}

Correspondence to: M. Schwikowski

(margit.schwikowski@psi.ch)

\section{Introduction}

Atmospheric aerosol particles affect global climate and air quality, thus having impact on human welfare and human health (e.g. Brimblecombe, 1987; Penner et al., 1994; IPCC, 2001; Davidson et al., 2005). The so-called aerosol forcing is based on a change of the earth's radiation balance, which controls our climate (e.g. Chylek and Coakley Jr., 1974; Crutzen and Ramanathan, 2003). Simplified, two main effects can thereby be distinguished, a direct effect, involving absorption and scattering of solar radiation, and an indirect effect since aerosol particles act as cloud condensation nuclei and enhance the formation of clouds (e.g. Novakov and Penner, 1993; Haywood, 1997; Jacobson, 2002). The strength of these effects and whether they result in a net cooling or net warming of the atmosphere is dependent on particle concentration, size and composition (Jacobson, 2002; Crutzen and Ramanathan, 2003; Davidson et al., 2005). At the time, the magnitude of the mostly negative aerosol forcing (cooling) associated with anthropogenic aerosols is highly uncertain (IPCC, 2001). Carbonaceous particles (CP) are a major component of the atmospheric aerosol and consist of two main fractions, organic carbon (OC) and elemental carbon (EC). OC is emitted either directly as aerosol particle or is formed from gaseous precursors as secondary organic aerosol. The origin of EC is primarily direct particle emission, nowadays mainly from anthropogenic sources (Slater et al., 2002; Szidat et al., 2004a). According to their different sources and ways of emission (direct or as gaseous precursors), both fractions differ in their composition and size and thus contribute differently to the climate forcing. Especially EC is thought to be highly relevant due to its high absorption and is discussed to be one of the most important anthropogenic constituent

Published by Copernicus GmbH on behalf of the European Geosciences Union. 


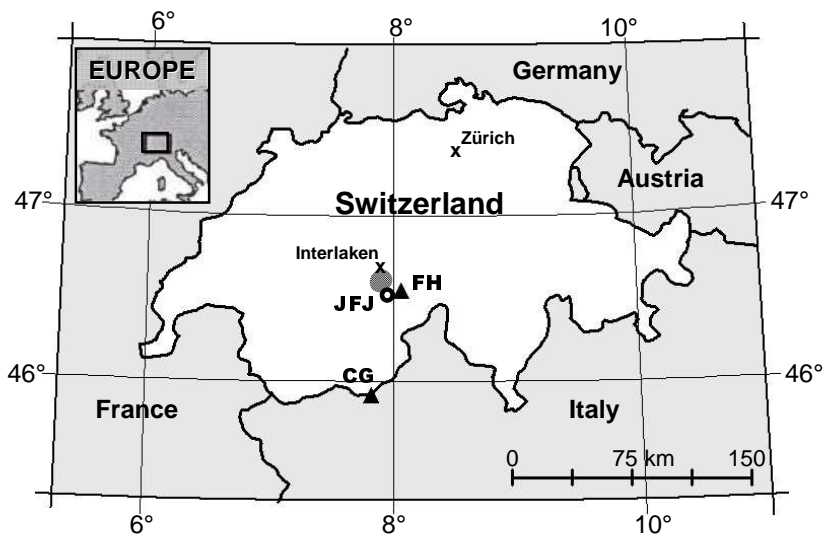

Fig. 1. Map of Switzerland and neighbouring European countries. Indicated are the FH and Colle Gnifetti (CG) drilling sites (triangles), the high alpine research station JFJ (open circle), the region of local emissions from mountain railways (shaded area, discussed in Sect. 3.5) and the two cities Interlaken and Zürich (x).

to global warming after $\mathrm{CO}_{2}$ (Hansen and Sato, 2001; Jacobson, 2002). Additionally, EC is known to enhance the melting process of snow and ice packs by increasing the absorbance of solar energy (ice-albedo feedback) (Clarke and Noone, 1985; Jacobson, 2004). As over 30\% of the earth's surface is seasonally covered by snow and ice, this leads to a further and additional climate response (albedo-temperature feedback) (Groisman et al., 1993; Hansen and Nazarenko, 2004; Jacobson, 2004).

${ }^{14} \mathrm{C}$ analysis offers a unique potential for unambiguous source apportionment of CP due to the possibility of a direct distinction of contemporary and fossil carbon (Szidat et al., 2004b; Currie, 2000; Lemire et al., 2002; Reddy et al., 2002). The separation of OC and EC can be achieved based on their specific thermal and chemical properties (Jacobsen, 2000; Petzold and Niessner, 1995). Ambient concentrations of $\mathrm{CP}$ are rather inhomogeneous, representing a complex mixture of primary and secondary particles. Long-range transport enables a mixing of the two species over space and time. Urban as well as rural pollution can contribute to the finally deposited particles. Despite their short mean atmospheric residence time of about one week, they can be detected in remote areas such as high-elevation glaciers (Lavanchy et al., 1999a, b; Bazhev et al., 1998; Holdsworth et al., 1996) and polar ice sheets (Cachier and Pertuisot, 1994; Chylek et al., 1992, 1995) where they are scavenged from the atmosphere during snowfall (Baltensperger et al., 1998). So far, data of CP concentrations from direct measurements exist only for short time periods (Sharma et al., 2004). There is still a large uncertainty about the contribution of biogenic and anthropogenic sources to these particles, especially for historical emissions. As ice cores allow access to samples representing climate and atmospheric conditions in the past, investigation of $\mathrm{CP}$ precipitated and stored in mid-latitude glaciers might help to overcome the lack of long-term data. The knowledge of past concentrations and sources is essential to understand their effect on climate conditions and might allow a better distinction from other anthropogenic or natural climate driving factors, finally resulting in improved models to predict future climate scenarios.

In this work, we present an ice-core record of past concentrations of the two main carbonaceous particle fractions, water-insoluble organic carbon (OC) and elemental carbon (EC). We quantified the natural and anthropogenic sources in the past, using the fraction of modern carbon $\left(\mathrm{f}_{M}\right)$ determined by microgram ${ }^{14} \mathrm{C}$ AMS analysis. Additional stable carbon isotope $\left(\delta^{13} \mathrm{C}\right)$ analysis was performed and results will be discussed. The record spans the time period 16501940, covering the transition from the pre-industrial to the industrial era. The time span between 1940 and present was not analysed since the technique applied could only be used for ice but not for snow and firn samples due to decontamination difficulties of these less dense samples.

\section{Experimental methods}

\subsection{Ice core recovery and dating}

In December 2002 a $150.5 \mathrm{~m}$ long ice core reaching bedrock was extracted from the Fiescherhorn glacier $(\mathrm{FH}$, $46^{\circ} 33^{\prime} 3.2^{\prime \prime} \mathrm{N}, 08^{\circ} 04^{\prime} 0.4^{\prime \prime} \mathrm{E} ; 3900 \mathrm{~m}$ a.s.l.) in the Bernese Oberland (Switzerland), approximately $6 \mathrm{~km}$ east of the high alpine research station Jungfraujoch (JFJ) (Fig. 1). The Fiescherhorn glacier was known before to be suitable as natural archive of past atmospheric composition (Schotterer et al., 1998; Schwikowski et al., 1999a; Huber, 2001). The annual net accumulation rate at this site is about $1.4 \mathrm{~m}$ water equivalent ( $\mathrm{m}$ weq) and snow fall is rather equally distributed over all four seasons.

Dating of the ice core was performed by annual layer counting (ALC) using the stable hydrogen isotope ratio $\delta \mathrm{D}$ (back to 1840) and the ammonium concentration as seasonally varying parameters (back to 1668 at a depth of $150 \mathrm{~m}$ (123.9 m weq.)). The deepest $50 \mathrm{~cm}$ of the core were not analysed for chemical tracers due to bad ice quality. Thus, dating had to be extrapolated for this part, resulting in additional 20 years. An ice flow model based on physical parameters and applied to $\mathrm{FH}$, gives an age of 274 years at $145 \mathrm{~m}$ (Schwerzmann et al., 2006), differing from the dating by ALC in the lowermost $5 \mathrm{~m}$ of the core by only 25 years. This is in accordance with the estimated dating uncertainties of ALC, which are increasing from top to bottom of the core with $\pm 2-5$ years for the period 1940-1900, $\pm 5-10$ years for 1900-1800 and $\pm 10-25$ years for 1800-1650.

During ice core drilling, the obtained core sections of about $70 \mathrm{~cm}$ length and $8 \mathrm{~cm}$ diameter were handled wearing gloves all the times. They were packed right after extraction into polyethylen tubes to prevent contamination. The ice 
core sections were then transported in frozen condition to the laboratory for further treatment.

\subsection{Sample preparation}

Cutting of the ice core sections and removal of possibly contaminated outer layers was performed in a cold room $\left(-20^{\circ} \mathrm{C}\right)$ using a pre-cleaned stainless-steel band saw. Different spatial resolution was chosen for the analysis of major ions by ion chromatography (Eichler et al., 2000), stable isotopes in water $\left(\delta \mathrm{D}, \delta^{18} \mathrm{O}\right)$ by isotope ratio mass spectrometry (IRMS) and carbonaceous particles. After cutting, samples were stored frozen in pre-cleaned containers (PETG, Semadeni) until further treatment or analysis. All steps described in the following were carried out in a class 100 laminar flow-box; materials used were made of quartz, glass, stainless steel or Teflon if not marked differently. All parts were pre-cleaned prior to use by brushing, rinsing with ultrapure water (MilliQ, $18 \mathrm{M} \Omega \mathrm{cm}^{-1}$ quality) and pre-heating. For the analysis of carbonaceous particles an additional decontamination step was performed to exclude possible input of dust and fibres from clothes worn in the cold room. For this purpose, the frozen samples of $0.4-1 \mathrm{~kg}$ ice were rinsed with ultra-pure water (mass loss 10 to $20 \%$ ) to remove surface contamination. Afterwards they were transferred into new, pre-cleaned containers which were closed for melting at room temperature. To collect the water-insoluble carbonaceous particles contained in the ice, the liquid samples were filtered through pre-heated $\left(12 \mathrm{~h}\right.$ at $\left.1000^{\circ} \mathrm{C}\right)$ quartz fibre filters (PallFlex Tissuquartz, 2500QAO-UP), which were afterwards acidified three times with $50 \mu \mathrm{L} 0.2 \mathrm{M} \mathrm{HCl}$ to remove carbonates before they were finally stored to complete dryness (Lavanchy et al., 1999a) For additional details see Jenk et al. (2006). Since the decontamination by rinsing with ultra-pure water is not applicable for porous snow and firn samples as they would take up the water, we analysed only samples from below the firn/ice transition (see also Sect. 2.6).

\subsection{Separation of OC and EC}

The method we applied to separate OC and EC in carbonaceous particles and the subsequent microgram-level ${ }^{14} \mathrm{C}$ AMS analysis was initially developed for ambient aerosol samples (Szidat et al., 2004a, b, c). Details for the application on ice samples can be found in Jenk et al. (2006). In short, filters with the water-insoluble carbonaceous particles were combusted stepwise at $340^{\circ} \mathrm{C}$ and $650^{\circ} \mathrm{C}$ to separate $\mathrm{OC}$ from EC. No well-defined transition exists between these fractions. Already very small amounts of remaining OC could result in a large artefact to the $\mathrm{EC}^{14} \mathrm{C} /{ }^{12} \mathrm{C}$ ratio in case this ratio is strongly different in the two fractions. Therefore, a complete separation of OC was necessary and an additional thermal elimination step of OC $(4 \mathrm{~h}$ at $375^{\circ} \mathrm{C}$ ) prior to combustion at $650^{\circ} \mathrm{C}$ was performed (Szidat et al., 2004c). Formed $\mathrm{CO}_{2}$ was cryogenically trapped and its volume determined manometrically (detection limit $<0.2 \mu \mathrm{g}$ carbon). A 2-5\% aliquot for $\delta^{13} \mathrm{C}$ IRMS analysis was separated and sealed in an evacuated glass tube. The remaining $\mathrm{CO}_{2}$ was sealed in a quartz tube for transformation to filamentous carbon and subsequent ${ }^{14} \mathrm{C}$ AMS analysis. As we extracted the carbonaceous particles from the liquid phase by filtration, OC and EC discussed in this study has always to be considered as the water-insoluble part of those fractions only. The water-insoluble part of OC can be best compared to what is described as WINSOC in Szidat et al. (2006). As discussed above, we had to perform an additional offline thermal elimination of OC in a muffle furnace, necessary for the subsequently performed AMS analysis. Unfortunately this procedure resulted in a loss of EC. Using the described setup, the average mass of EC removed by this procedure of $50 \pm 8 \%$ was determined through analysis (with and without the additional step) of aerosol samples collected at the highalpine site JFJ and in the city of Zürich (Switzerland). To make our results comparable to other studies of OC and EC concentrations, measured EC values were accordingly multiplied by a factor of $2.0 \pm 0.3$.

\section{$2.4{ }^{14} \mathrm{C}$ AMS and $\delta^{13} \mathrm{C}$ IRMS analysis}

The method of target preparation of microgram carbon samples using manganese and cobalt is based on previous work by Szidat et al. (2004c) with modifications for the specific requirements of ice samples (Jenk et al., 2006). Measurements of the ${ }^{14} \mathrm{C} /{ }^{12} \mathrm{C}$ ratio were performed on a $500 \mathrm{kV}$ pelletron compact AMS system (Synal et al., 2000). Details of the target production, measurement parameters, data evaluation and corrections for microgram samples can be found in Szidat et al. (2004c) and Jenk et al. (2006). In short, the procedural blank for ice samples of the analysed size was $1.3 \pm 0.6 \mu \mathrm{g}$ OC with a $\mathrm{f}_{M}=0.6 \pm 0.1$ and $0.3 \pm 0.1 \mu \mathrm{g}$ EC with an estimated $\mathrm{f}_{M}=0.3 \pm 0.3$. AMS calibration was performed using internal standards and blanks and we corrected for fractionation, for constant contamination during the processing of these ultra-small carbon samples (Hua et al., 2003) and subtracted the procedural blank of ice samples. The repeated analysis of processed reference material resulted in agreement with consensus values and standard deviations were $\mathrm{f}_{M}= \pm 0.02(1 \sigma) .{ }^{13} \mathrm{C} /{ }^{12} \mathrm{C}$ ratios of $\mathrm{CO}_{2}$ were additionally measured offline by IRMS (Delta Plus XL, Thermo-Finnigan) equipped with gasbench- and preconperiphery (Thermo-Finnigan). With this set-up we reached standard deviations of $0.13 \%$ o for the repeated anaysis of gaseous NBS Oxalic Acid standard (HOxI) and $0.19 \%$ for processed reference material (Jenk et al., 2006). $\delta^{13} \mathrm{C}$ values are given as relative deviations from the international carbon reference standard "Vienna Pee Dee Belemnite" (V-PDB) in per mil. 


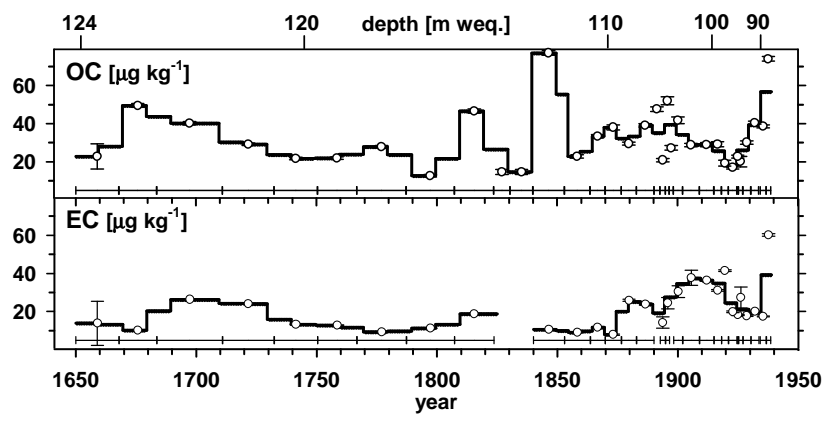

Fig. 2. Records of water-insoluble OC and EC concentrations in $\mu \mathrm{g} \mathrm{kg}^{-1}$ ice for the years $1650-1940$ (89-124 m weq). Shown is a weighted average (solid line) of the individual analysed samples (open circles). Uncertainties ( $1 \sigma)$ of single measurements are indicated as error bars. The resolution of this average is 5 years back to 1850 and 10 years back to 1650 , according to the resolution of the individual samples (horizontal bars).

\subsection{Presentation of ${ }^{14} \mathrm{C}$ results}

In the following, ${ }^{14} \mathrm{C}$ AMS results will be given as fraction of modern carbon $\left(\mathrm{f}_{M}\right)$. This term can be transferred into percent of modern carbon (pMC) as defined in Stuiver and Polach (1977) using the formula: $\mathrm{pMC}=\mathrm{f}_{M} \times 100$. Accordingly, $\mathrm{f}_{M}$ includes correction for the decay (reference year 1950 until the year of measurement in 2004 or 2005) and correction for the chronological age of the sample. Different from this definition, results of $\mathrm{f}_{M}$ additionally include normalization to the IntCal04 Northern Hemisphere radiocarbon calibration curve (Reimer et al., 2004) in this study, which considers the fact that the atmospheric ${ }^{14} \mathrm{C} /{ }^{12} \mathrm{C}$ ratio is varying over time. Hence, $\mathrm{f}_{M}$ as defined here directly indicates the ${ }^{14} \mathrm{C}$ content of a sample relative to the ${ }^{14} \mathrm{C}$ content in the living biosphere at the corresponding time. In summary, a sample with $\mathrm{f}_{M}=1$ consisted $100 \%$ of contemporary carbon at the time of snow deposition on the glacier, and a sample with $\mathrm{f}_{M}=0$ contained pure fossil carbon.

\subsection{Time resolution}

We analysed 33 samples, extracted from 0.4 to $1 \mathrm{~kg}$ ice originating from the part of the core below the firn/ice transition (Sect. 2.2). The time period covered by the samples is 1650 to 1940 . The spatial resolution of samples analysed for OC was $70-140 \mathrm{~cm}$, depending on ice quality and concentrations. Consequently, the time resolution varied between $1-10$ and $10-30$ years for the periods $1940-1850$ and 1850 1650 , respectively. Due to the lower EC concentration, two samples analysed for OC had to be pooled for ${ }^{14} \mathrm{C}(\mathrm{EC})$ analysis, resulting in reduced resolution (1940-1900: 1-10 years; 1900-1650: 10-50 years). Even so, amounts were extremely low with only 9 to $20 \mu \mathrm{g} \mathrm{C}$. Such small amounts of carbon are pushing the limits of AMS. The failure rate, due to measurements close to the detection limit and instable conditions, was accordingly higher than for routine measurements. For that reason, 3 out of 14 EC samples and 7 out of 33 OC samples could not be analysed, resulting in a number of gaps in the records. The $\delta^{13} \mathrm{C}$ record is also not continuous, since $\mathrm{CO}_{2}$ aliquots were only separated if the remaining $\mathrm{CO}_{2}$ was sufficient for subsequent AMS analysis.

The concentrations of major ions presented in Sect. 3.3., were derived from samples analysed by ion chromatography. They were cut with a spatial resolution of $3 \mathrm{~cm}, 2 \mathrm{~cm}$ and $1.5 \mathrm{~cm}$ for the time periods $1940-1915,1910-1900$ and 1900-1670, respectively, resulting in sub-annual signals. To compare the results with the $\mathrm{CP}$ record, 5 to 10 year averages were calculated.

\section{Results and discussion}

\subsection{Record of OC and EC concentrations}

Records of OC and EC concentration are presented in Fig. 2. The averaged relative uncertainty of all samples is $4 \%$ and $18 \%$ for OC and EC, respectively (the high uncertainty of EC is explained by the necessary correction with a factor of $2.0 \pm 0.3$ as described in Sect. 2.3). OC concentrations show high and abrupt fluctuations around a mean of $33 \mu \mathrm{g} \mathrm{kg}^{-1}$ (range: 13 to $77 \mu \mathrm{g} \mathrm{kg}^{-1}$ ). No concentration trend was observed for the examined time period (1650-1940). Relatively high concentrations were found from 1670-1730, 18101820 and 1840-1855, which will be further discussed in Sect. 3.5. EC concentrations show a more steady behaviour and the mean value of $22 \mu \mathrm{g} \mathrm{kg}^{-1}$ (range: 8 to $60 \mu \mathrm{g} \mathrm{kg}^{-1}$ ) is lower than the $\mathrm{OC}$ mean. A significant correlation between $\mathrm{EC}$ and $\mathrm{OC}$ concentrations exists if excluding the two samples around 1850 (see Sect. 3.5). In contrast to the OC record, a trend to higher concentrations after $\sim 1870$ was observed for EC. This reflects the anthropogenic influence due to industrialisation and the corresponding extended use of fossil fuels (Penner et al., 1993). The average EC concentration from 1870 to $1940\left(27 \mu \mathrm{g} \mathrm{kg}^{-1}\right)$ is significantly higher than in the period from 1650 to $1870\left(15 \mu \mathrm{g} \mathrm{kg}^{-1}\right)$. Relatively high concentrations were detected in the two samples around $1680-1730$ and the sample around 1810-1825. During these periods additional contribution from mineral dust events can not be excluded (Sect. 3.3). Without these samples, average EC concentrations from 1650 to $1870\left(12 \mu \mathrm{g} \mathrm{kg}^{-1}\right)$ were lower by more than a factor of 2 than the ones during the anthropogenic influenced era (1870 to 1940). Presented results are summarized in Table 1. Our results are in general agreement with an earlier study of an ice core record from Colle Gnifetti (Fig. 1) by Lavanchy et al. (1999a). Concerning the limitations of this earlier work - only $36 \%$ of the ice which covered the recorded time-period was analysed and thus resulted in a discontinuous record - similarities in the main structure and trend of the two records can still be observed. 
Table 1. The biogenic and anthropogenic carbon contribution to $\mathrm{OC}$ and $\mathrm{EC}$ are given as weighted averages for different time periods with the observed range in parentheses. $\mathrm{OC}_{b}, \mathrm{OC}_{f}, \mathrm{EC}_{b}, \mathrm{EC}_{f}$ denote the biomass and fossil contribution to the $\mathrm{OC}$ and $\mathrm{EC}$ concentration, respectively. The presented biogenic background is the average value for the time before 1800 ( $\pm 1 \sigma$, standard deviation). Additionally, the values observed for the year 1940 are given with uncertainties of analysis $( \pm 1 \sigma)$.

\begin{tabular}{|c|c|c|c|c|c|c|c|c|}
\hline $\begin{array}{l}\text { Time } \\
\text { period }\end{array}$ & & $1650-1800$ & $1800-1850$ & $1850-1870$ & 1870-1900 & 1900-1940 & $\begin{array}{l}\text { biogenic } \\
\text { background }\end{array}$ & Year 1940 \\
\hline \multirow[t]{5}{*}{$\mathrm{OC}$} & Concentration $\left[\mu \mathrm{g} \mathrm{kg}^{-1}\right]$ & $29(13-50)$ & $37(15-77)$ & $34(23-33)$ & $36(21-52)$ & $32(17-74)$ & - & - \\
\hline & Contemporary carbon [\%] & $89(83-99)$ & $86(81-91)$ & $88(84-90)$ & $65(12-88)$ & $79(55-97)$ & $89 \pm 6$ & $55 \pm 1$ \\
\hline & Fossil carbon $[\%]$ & $11(1-17)$ & $14(9-19)$ & $12(10-16)$ & $35(12-88)$ & $21(3-45)$ & $11 \pm 6$ & $45 \pm 1$ \\
\hline & $\mathrm{OC}_{b}\left[\mu \mathrm{g} \mathrm{kg}^{-1}\right]$ & $26(20-42)$ & $32(11-62)$ & $30(21-33)$ & $24(6-41)$ & $25(16-41)$ & $25 \pm 7^{\mathrm{a}}$ & $41 \pm 1^{b}$ \\
\hline & $\mathrm{OC}_{f}\left[\mu \mathrm{g} \mathrm{kg}^{-1}\right]$ & $4(<3-8)$ & $6(<3-14)$ & $4(<3-5)$ & $13(<3-46)$ & $8(<3-33)$ & $<3^{\mathrm{a}}$ & $33 \pm 1$ \\
\hline \multirow[t]{5}{*}{$\mathrm{EC}$} & Concentration $\left[\mu \mathrm{g} \mathrm{kg}^{-1}\right]$ & $16(9-26)$ & $15(11-19)$ & $10(9-12)$ & $21(8-26)$ & $31(17-60)$ & - & - \\
\hline & Contemporary carbon [\%] & - & $52(49-58)$ & $55(48-58)$ & $31(24-31)$ & $30(17-35)$ & $58 \pm 6^{\mathrm{c}}$ & $17 \pm 2$ \\
\hline & Fossil carbon $[\%]$ & - & $48(42-51)$ & $45(42-52)$ & $69(69-76)$ & $70(65-83)$ & $42 \pm 6^{c}$ & $83 \pm 2$ \\
\hline & $\mathrm{EC}_{b}\left[\mu \mathrm{g} \mathrm{kg}^{-1}\right]$ & - & $6(6)$ & $6(5-6)$ & $6(5-9)$ & $9(5-11)$ & $6 \pm 1^{\mathrm{c}, \mathrm{d}}$ & $10 \pm 2$ \\
\hline & $\mathrm{EC}_{f}\left[\mu \mathrm{g} \mathrm{kg}^{-1}\right]$ & - & $4(4)$ & $5(4-5)$ & $15(5-19)$ & $22(13-50)$ & $4 \pm 1^{\mathrm{c}, \mathrm{d}}$ & $50 \pm 9$ \\
\hline
\end{tabular}

a The 1670 period of extremely high OC concentration due to forest fires was excluded (Sect. 3.5).

$\mathrm{b}$ No trend to higher levels was observed in $\mathrm{OC}_{b}$ over time, thus this high value can most probably be explained by the observed large variability.

${ }^{\mathrm{c}}$ Level $\sim 1850$ (most probably higher than the actual biogenic background).

$\mathrm{d}$ The period 1680-1730 probably influenced by Saharan dust layers was excluded (Sect. 3.3).

As only summer snow is accumulated at Colle Gnifetti, OC concentrations were significantly higher there.

\subsection{Source contribution to OC and EC based on ${ }^{14} \mathrm{C}$ analy- sis}

In Fig. 3 the $\mathrm{OC}$ and $\mathrm{EC}$ records of ${ }^{14} \mathrm{C} /{ }^{12} \mathrm{C}$ ratios are presented as $\mathrm{f}_{M}$ (see Sect. 2.5). The averaged uncertainty of $\mathrm{f}_{M}$ including all samples is 5\% and $11 \%$ for OC and EC, respectively.

A significant contribution of anthropogenic (fossil) sources after $\sim 1870$ can be identified in both fractions, in agreement with the observed increase of EC concentrations. However, there is no constantly increasing contribution of fossil fuels, neither in the OC nor in the EC record as it would be expected based on estimated emissions (Penner et al., 1993). Instead, the data suggest a major emission source, leading to a clear signal from 1870-1900 with a maximum around 1890 (detailed discussion in Sect. 3.5). Nevertheless, the general trend reveals a more and more dominating contribution of anthropogenic sources after 1870, accordingly the relative biogenic carbon contribution is decreasing for both fractions (Table 1). Values for 1940 show a fossil contribution of $45 \pm 1 \%$ and $83 \pm 2 \%$ to the OC and EC concentrations, respectively, approaching the annual mean value of the year 2002 in urban aerosol samples from Zürich (Szidat et al., 2006). Although the consumption of fossil fuels is by factors higher today, the relative contributions of anthropogenic emissions to OC and EC around 1940 seem to be comparable. This may be due to the fact that these early emissions

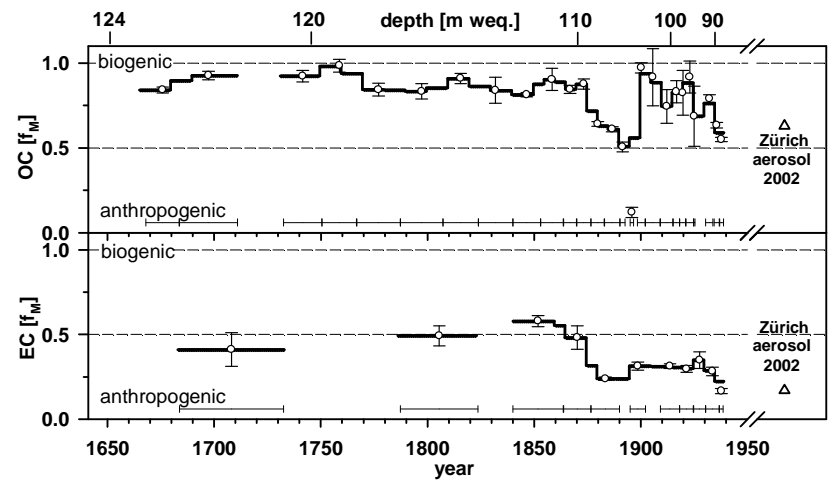

Fig. 3. OC and EC $\mathrm{f}_{M}$-records for the years 1650-1940 (see Sect. 2.5 for definition of $\mathrm{f}_{M}$ ). Shown is a weighted average (solid line) of the individual analysed samples (open circles, resolution see Fig. 2). For single measurements, overall uncertainties of ${ }^{14} \mathrm{C}$ AMS analysis $(1 \sigma)$ are indicated as error bars. Triangles give annual mean values for recent aerosol (Zürich, 2002, Fig. 1) (Szidat et al., 2006). Both records, $\mathrm{f}_{M}$ (OC) and (EC) reflect the increased combustion of fossil fuels after the beginning of the industrialisation around 1860-1870.

were not subjected to any air pollution control measures (e.g. introduction of filters in power plants). Before $\sim 1850$, OC was approaching purely biogenic origin with a mean $\mathrm{f}_{M}$ of 0.88 and a standard deviation of $0.06(\mathrm{n}=10)$. The anthropogenic contribution to EC emissions from the use of fossil fuels before 1850 was already significant with about $50 \%$ according to the results of the two analysed samples. This 


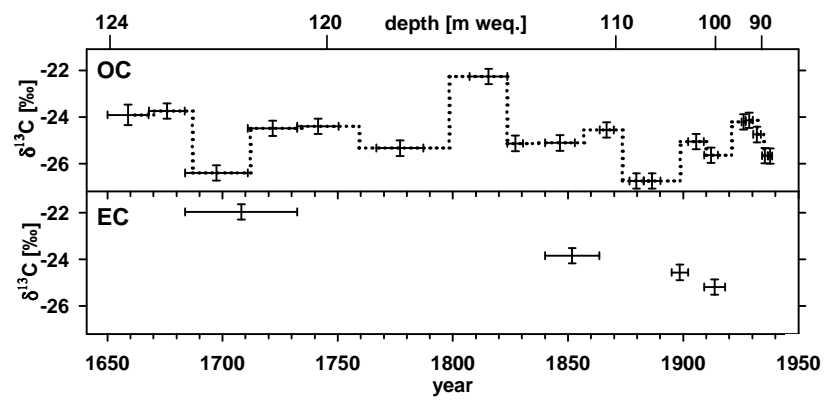

Fig. 4. $\delta^{13}$ C-records of OC and EC for the years 1650-1940. Vertical error bars indicate overall uncertainties of IRMS analysis $(1 \sigma)$, horizontal bars indicate the sample resolution along the ice core. Small dots are used to guide the eye.

is unexpected and it seems as if this value is at least partly influenced by airborne mineral dust (Sect. 3.3). Results are summarized in Table 1.

\subsection{Record of $\delta^{13} \mathrm{C}$}

In Fig. 4 the $\delta^{13} \mathrm{C}$ records of $\mathrm{OC}$ and $\mathrm{EC}$ are presented. No long-term trend was observed in the $\delta^{13} \mathrm{C}$ of OC. The average is $-24.9 \pm 1.1 \%$ o $(1 \sigma)$, a value typical for biogenic emissions from C3-plants (Boutton, 1991). When excluding the two samples representing the years around 1700 and 1810 (see discussion below), the record nicely follows the structure of the OC $\left[\mathrm{f}_{M}\right]$ and $\mathrm{EC}\left[\mathrm{f}_{M}\right]$ records in Fig. 3. In OC, we found good correlation between $\mathrm{f}_{M}$ and $\delta^{13} \mathrm{C}$ with $r^{2}=0.35$ $(\mathrm{n}=14)$ and $\delta^{13} \mathrm{C}$ values for pure biogenic and fossil $\mathrm{OC}$ with $-24.3 \pm 0.4 \%$ and $-28.2 \pm 1.2 \%$, respectively, were determined by a linear regression. Only few studies exist, discussing how mixing of biogenic and fossil carbon sources is reflected in a $\delta^{13} \mathrm{C}$ variation. Our results are in agreement and within the same range of today's knowledge that a relatively low $\delta^{13} \mathrm{C}$ value corresponds to carbon derived from fossil sources (e.g. Pataki et al., 2003; Widory et al., 2004; Loh et al., 2004). For EC, going back in time, the record reveals a trend to samples which are less ${ }^{13} \mathrm{C}$ depleted (1900: $-25.2 \pm 0.3 \%$; $1850:-23.8 \pm 0.3 \%$ ). This might reflect a decreased anthropogenic influence by fossil carbon (Pataki et al., 2003).

Saharan dust layers were visually and chemically detected in the FH ice core and filters prepared from the according ice sections showed higher amounts of mineral dust particles as well as a characteristic brown discoloration after the applied thermal analysis at $650^{\circ} \mathrm{C}$ similar to what was described by Lavanchy et al. (1999b). In such samples, we probably can not fully exclude an artefact to the presented records due to carbonates. Eglinton et al. (2002) described that dust from Sahara and Sahel regions is a natural source of old $\left({ }^{14} \mathrm{C}\right.$ depleted) particulate matter (PM) also characterised by high $\delta^{13} \mathrm{C}$ values. The $\mathrm{OC}\left[\delta^{13} \mathrm{C}\right]$ values in samples including higher amounts of dust (1680-1710: $-26.4 \pm 0.3 \%$; 1710-
1730: $-24.5 \pm 0.3 \%$; $1810-1825:-22.3 \pm 0.3 \%$ ) might thus indicate different source regions of the dust. However, no evidence was found, that the Saharan dust layers do affect the concentration and $\mathrm{OC}\left[\mathrm{f}_{M}\right]$ records. As suggested in Sects. 3.1 and 3.2, different from this, the EC fraction might be influenced. A $50 \%$ fossil contribution to EC before 1850 seems unlikely as fossil fuels just started to become an important energy source at this time (Sect. 3.2). The $\delta^{13} \mathrm{C}$ value of the one EC sample including Saharan dust (16801730) was $-22.0 \pm 0.3 \%$ o, which is significantly higher than observed for the other three anthropogenic influenced samples (see above). Based on this and the above mentioned study from Eglinton et al. (2002), we can not exclude that the $\mathrm{EC}\left[\mathrm{f}_{M}\right]$ values of the samples covering the time period $\sim 1680-1730(\mathrm{n}=1)$ and $\sim 1790-1820(\mathrm{n}=1$, see also Sect. 3.2 and Fig. 3) as well as the high concentrations in the three EC samples (1680-1730: $n=2 ; 1810-1825: n=1)$ are an artefact of Saharan dust events rather than reflecting anthropogenic emissions. Anyway, whether the reason why EC $\left[\mathrm{f}_{M}\right]$ does not approach a value of 1 as expected for samples before $\sim 1800$ is a methodical problem or a surprising property of natural EC aerosol should be further investigated in the future.

\subsection{Apportionment of emission sources}

Based on the concentration and the corresponding $\mathrm{f}_{M}$, we calculated source dependent concentrations of OC and EC. When ${ }^{14} \mathrm{C}$ was not analysed, the averaged value for the according time period as presented in Table 1 was used $\left(\mathrm{f}_{M}=0.58\right.$ was used for EC before 1850). Absolute values presented in the following for the biogenic and fossil OC $\left(\mathrm{OC}_{b}, \mathrm{OC}_{f}\right)$ and $\mathrm{EC}\left(\mathrm{EC}_{b}, \mathrm{EC}_{f}\right)$ fractions have an uncertainty of $\pm 6 \%$ and $\pm 21 \%$, respectively ( $1 \sigma$, estimated by error propagation of the averaged uncertainties from concentration and ${ }^{14} \mathrm{C}$ analysis). For the $\mathrm{EC}_{b}$ and $\mathrm{EC}_{f}$ records, samples for which an influence from Saharan dust has to be considered were not included (Sect. 3.3), resulting in the two gaps. In Fig. 5, the results are presented and compared with concentration records of specific chemical tracers of ammonium $\left(\mathrm{NH}_{4}^{+}\right)$and sulphate $\left(\mathrm{SO}_{4}^{2-}\right)$, which are attributed to either biogenic or anthropogenic sources. Overall results are summarized in Table 1. Ammonium is a tracer of forest fires (Levine et al., 1992) but is also related to emissions from agriculture and vegetation. Sulphate originates from different natural and anthropogenic sources. $\mathrm{ExSO}_{4}^{2-}$ is the total $\mathrm{SO}_{4}^{2-}$ corrected for the sea-salt and mineral dust contribution and is assumed to originate exclusively from oxidation of $\mathrm{SO}_{2}$ in the atmosphere with mainly anthropogenic sources in the last 150 years (Schwikowski et al., 1999b).

$\mathrm{OC}_{b}$ concentrations show no trend, but rather large variations over the analysed time period (1650-1940). The two periods with significantly higher concentrations in the 1670s and around 1850 are attributed to special events (see Sect. 3.5). Excluding these two periods, correlation between 
$\mathrm{OC}_{b}$ and $\mathrm{NH}_{4}^{+}$concentrations was found. The correlation is even better for the time after 1850, indicating common sources such as the extensive use of wood as bio-fuel and an increased agricultural activity. The biogenic background level of $\mathrm{OC}_{b}$ was $24 \mu \mathrm{g} \mathrm{kg}^{-1}$ with a standard deviation of $7 \mu \mathrm{g} \mathrm{kg}^{-1}$. For $\mathrm{EC}_{b}$ it was $6 \mu \mathrm{g} \mathrm{kg}^{-1}$ with a standard deviation of $1 \mu \mathrm{g} \mathrm{kg}^{-1}$. The biogenic background level was defined as the averaged value for the time period before 1800 , excluding the 1670 period (probably reflecting forest fire events) and the period 1680-1730 (probably influenced by Saharan dust layers) for OC and EC, respectively. No correlation between $\mathrm{OC}_{b}$ and $\mathrm{EC}_{b}$ was found. Because $\mathrm{OC}_{b}$ reflects gaseous or particulate emissions from vegetation as well as gaseous precursors from biomass burning, whereas $\mathrm{EC}_{b}$ exclusively originated from particulate emissions during combustion of biomass one would expect a weak correlation at the most.

For $\mathrm{OC}_{f}$ and $\mathrm{EC}_{f}$ the biogenic background level was below $3 \mu \mathrm{g} \mathrm{kg}^{-1}$ (detection limit) and $4 \pm 1 \mu \mathrm{g} \mathrm{kg}^{-1}$, respectively. Both fractions strongly increased after 1870 comparable to $\mathrm{xSO}_{4}^{2-}$ and black carbon (BC) emissions from hard coal and petroleum combustion estimated for Switzerland and surrounding countries (Penner et al., 1993). The rapid increase in $\mathrm{OC}_{f}$ between 1870 and 1900 can be explained by a local source (for detailed discussion see Sect. 3.5). After 1925 a second strong increase in $\mathrm{OC}_{f}$ was observed along with the onset of a strongly increased consumption of petroleum in Europe (1916-1925: $0.82 \mathrm{Tg} \mathrm{a}^{-1} ; 1926-1935$ : $9.37 \mathrm{Tg} \mathrm{a}^{-1}$ ) whereas the consumption of hard coal remained relatively constant on a much higher level (1916-1925: 773 $\mathrm{Tg} \mathrm{a}^{-1}$; 1926-1935: $873 \mathrm{Tg} \mathrm{a}^{-1}$ ) (Penner et al., 1993). This suggests that the combustion of petroleum results in much higher emissions of $\mathrm{OC}_{f}$ than the combustion of hard coal. For 1940, the additional input from anthropogenic (fossil) sources was $33 \pm 1 \mu \mathrm{g} \mathrm{kg}^{-1}$ and $50 \pm 9 \mu \mathrm{g} \mathrm{kg}^{-1}$ for $\mathrm{OC}_{f}$ and $\mathrm{EC}_{f}$, respectively. This is equivalent to an increase of the emissions of fossil carbon by a factor 10 for both fractions. As discussed in Sect. 3.2, the fossil fraction of samples from 1940 is comparable to that of recent urban aerosol samples from Zürich.

\subsection{Special events}

Four episodes are discussed in detail (Fig. 5: red (I-III) and blue (IV-V)):

I-III) High OC/EC ratios are characteristic for the combustion of wood (Szidat et al., 2006). We observed a baseline OC/EC ratio of $1.5 \pm 0.3(1 \sigma)$. This ratio is significantly higher in the 1670s (I: 4.9,), from 1770 to 1790 (II: 2.7), in the 1810s and in 1840-1875 (III: 2.5 and 4.7). Ice core data from Mt. Logan together with other data suggest a hemispheric signal of the rapid rise of biomass clearing and burning associated with agrarian activities in Northern America (Holdsworth et al., 1996). In the Mt. Logan core, this event was observed in $\mathrm{BC}$ concentrations. However, the peaks are

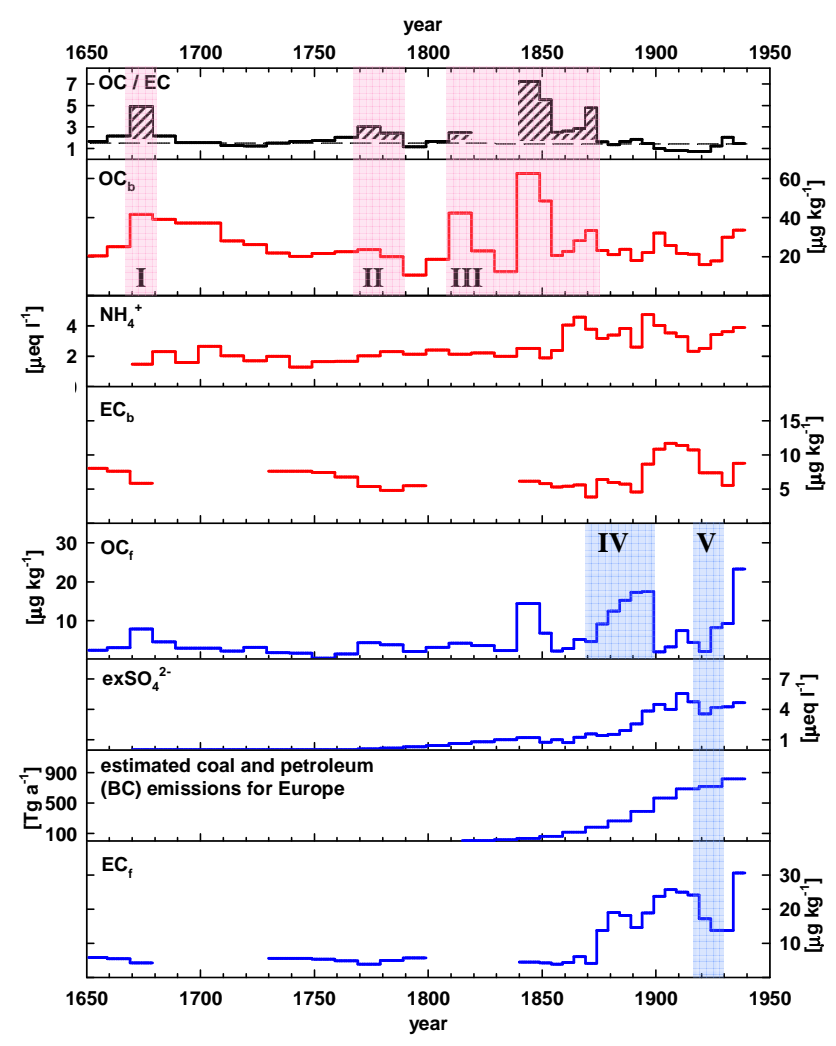

Fig. 5. Records of different tracers for biogenic emissions (red) and anthropogenic emissions (blue) together with the OC/EC ratio for the years 1650-1940. $\mathrm{OC}_{b}$ and $\mathrm{EC}_{b}$ represent the biogenic and $\mathrm{OC}_{f}$ and $\mathrm{EC}_{f}$ the fossil contribution to these fractions. The uncertainties of the presented concentration curves (weighted averages) are $6 \%$ and $21 \%$ for $\mathrm{OC}_{b / f}$ and $\mathrm{EC}_{b / f}$, respectively. The hatched areas in the OC/EC ratio record indicate events of wood combustion. The red coloured (I-III) and blue coloured areas (IV-V) highlight special events (see Sect. 3.5).

in good agreement with the increase in OC concentrations observed here and in elevated OC/EC ratios after 1800 and around 1850 (III). For the peak around 1780 (II), we assume a regional, much smaller source of wood combustion based on the lower OC concentration and OC/EC ratio. The signal observed in the second half of the 17th century (I) looks similar to III. There is no detailed knowledge or data about large land clearing and forest fires which could have led to a hemispheric or at least continental signal for these times.

IV) Between 1870 and 1900 we observed strongly increasing and finally very high $\mathrm{OC}_{f}$ concentrations (about a factor 8 higher than the natural background). The lowest $\mathrm{f}_{M}$ measured during this time period was 0.2 compared to 0.6 in recent aerosol samples from Zürich. Prepared filters from these ice layers showed a black coating, visibly different from a normally observed beige, brown, or slightly grey colouring. After 1870, the railway around Interlaken (Bödelibahn, 1872-1874) was integrated into the Swiss railway network (1888, 1890). After 1891, four mountain railways (Mürren, 
1891; Schynige Platte, 1893; Wengeneralp, 1893; Kleine Scheidegg, 1893, $2000 \mathrm{~m}$ a.s.l.) were built (Pfister, 1995), all of them located within 10 to $20 \mathrm{~km}$ of the FH (see Fig. 1). They were operated by steam locomotives, which were most probably the sources for the observed high $\mathrm{OC}_{f}$ concentrations during this time. The decrease of $\mathrm{OC}_{f}$ concentrations is explained by the stepwise electrification of these railways after 1900 .

V) At the time of decreased consumption of fossil fuels during the 1920s due to the world economic crisis, $\mathrm{EC}_{f}$ is clearly lower, whereas this is less pronounced in the sulphate record and seems to be underestimated by the reconstructed emission data. As discussed in Sect. 3.4, the observed decrease in $\mathrm{OC}_{f}$ most probably reflects the transition from hard coal to petroleum.

\subsection{Comparison of emission estimates and ice core data}

Our results of biogenic and anthropogenic contribution to $\mathrm{OC}$ $\left(\mathrm{OC}_{b}, \mathrm{OC}_{f}\right)$ and $\mathrm{EC}\left(\mathrm{EC}_{b}, \mathrm{EC}_{f}\right)$ (see online supporting material, Tables S1 and S2: http://www.atmos-chem-phys.net/ 6/5381/2006/acp-6-5381-2006-supplement.pdf) were compared with the dataset on historical emission inventories of carbonaceous particles from Junker and Liousse (2006) for the overlapping time period (1860-1940). The records are in good agreement for the according pairs of components (i.e. $\mathrm{OC}_{b} /$ biofuel OC; $\mathrm{EC}_{b}$ / biofuel $\mathrm{EC}, \mathrm{OC}_{f} /$ fossil OC and $\mathrm{EC}_{f}$ /fossil EC). However, one should be aware, that (i) the results presented by Junker and Liousse (2006) included emissions on a global scale, whereas our archive represents emissions on a regional (mid-European) scale. Thus, periods which are influenced by a local source in the ice core record can not directly be compared. (ii) The emission inventory considers only estimations for fossil-fuel and bio-fuel consumption, but neither for primary nor for secondary biogenic (vegetation) OC formation. This leads to an underestimation of the biogenic contribution to OC. Large differences between emission estimates and our results were accordingly found for the relative fossil and biogenic OC contribution in 1860. Whereas the inventory dataset still suggested fossil sources to be most important for OC emissions, radiocarbon determination reveals that $\sim 90 \%$ of OC originated from biogenic sources or bio-fuel burning. This underlines that biogenic OC significantly contributes to the total carbonaceous particle burden not only during the beginning of the industrial era but also today (Szidat et al., 2004b). (iii) Finally, carbonaceous particles were extracted by filtration from melted ice and water soluble OC could thus not be analyzed. Nevertheless, the two records are complementary and an extension of the covered time scales is achievable.

\section{Conclusions}

A long-term record of the two water insoluble main fractions of carbonaceous particles (EC and water-insoluble OC) is presented, based on the analysis of ice core samples extracted from the Fiescherhorn glacier in Switzerland. A new method, combining concentration measurements and ${ }^{14} \mathrm{C}$ AMS analysis of these fractions was applied for the first time on ice samples, covering the time period 16501940. This method allowed a distinction between the biogenic and anthropogenic contribution in ancient carbonaceous particles. OC was found to approach a purely biogenic origin before $\sim 1850$. Concentrations in 1940 were about a factor of 3 higher than the biogenic background level of $24 \mu \mathrm{g} \mathrm{kg}^{-1}$ ice with a standard deviation of $7 \mu \mathrm{g} \mathrm{kg}^{-1}$. This can be mainly attributed to the additional anthropogenic contribution from the combustion of fossil fuels with about $45 \%$. For pure biogenic and pure fossil OC we determined a $\delta^{13} \mathrm{C}$ value of $-23.4 \pm 0.4 \%$ and $-28.4 \pm 1.2 \%$, respectively. This parameter showed to be an additional and useful tracer for different biogenic and fossil carbon emissions, as a mixing of sources leads to a variation in $\delta^{13} \mathrm{C}$. The biogenic EC background concentration was $6 \mu \mathrm{g} \mathrm{kg}^{-1}$ ice with a standard deviation of $1 \mu \mathrm{g} \mathrm{kg}^{-1}$. In 1940, the fossil contribution to EC was $83 \pm 2 \%$. Thus, the additional anthropogenic input of atmospheric EC could be determined with $50 \pm 9 \mu \mathrm{g} \mathrm{kg}^{-1}$ ice for this time.

Acknowledgements. We thank the Swiss National Science Foundation for supporting this study through its National Center of Competence in Research (NCCR) on Climate. We are grateful to the Paul Scherrer Institut and the Swiss Federal Institute of Technology, jointly operating the Zürich AMS facilities. Special thanks go to the members of the expedition, who made this study possible by the extraction of the Fiescherhorn-Glacier ice core under harsh conditions.

Edited by: Y. Balkanski

\section{References}

Baltensperger, U., Schwikowski, M., Jost, D. T., Gäggeler, H. W., and Poulida, O.: Scavenging of atmospheric constituents in mixed phase clouds at the high-alpine site Jungfraujoch; Part I: Basic concept and cloud scavenging, Atmos. Environ., 32, 39753983, 1998.

Bazhev, A. M., Rototaeva, O., Heintzenberg, J., Stenberg, M., and Pinglot, J. F.: Phyiscal and chemical studies in the region of the southern slope of Mount Elbrus, Caucasus, J. Glaciol., 44, 214222, 1998.

Boutton, T. W.: Stable carbon isotope ratios of natural materials: II. Atmospheric, terrestrial, marine and freshwater environments, in: Carbon Isotope Techniques, edited by: Coleman, D. C. and Fry, B., San Diego, Academic Press, 173-185, 1991.

Brimblecombe, P.: The Big Smoke, Methunen, London, 1987.

Cachier, H. and Pertuisot, M. H.: Particulate carbon in Arctic ice, Analysis Magazine, 22, 34-37, 1994. 
Chylek, P. and Coakley Jr., A.: Aerosols and climate, Science, 183, 75-77, 1974.

Chylek, P., Johnson, B., and Wu, H.: Black carbon concentration in a Greenland DYE-3 ice core, Geophys. Res. Lett., 19, 19511953, 1992.

Chylek, P., Johnson, B., Damiano, P. A., Taylor, K. C., and Clement, P.: Biomass burning record and black carbon in the GISP2 ice core, Geophys. Res. Lett., 22, 89-92, 1995.

Clarke, A. D. and Noone, K. J.: Soot in the arctic snowpack: A cause for perturbations in radiative transfer, Atmos. Environ., 19, 2045-2053, 1985.

Crutzen, P. J. and Ramanathan, V.: The parasol effect on climate, Science, 302, 1679-1680, 2003.

Currie, L. A.: Evolution and multidisciplinary frontiers of ${ }^{14} \mathrm{C}$ aerosol science, Radiocarbon, 42, 115-126, 2000.

Davidson, I. C., Phalen, R. F., and Solomon, P. A.: Airborne particulate Matter and Human Health: A Review, Aerosol. Sci. Technol., 39, 737-749, 2005.

Eglinton, T. I., Eglinton, G., Dupont, L., Sholkovitz, E. R., Montlucon, D., and Reddy, C. M.: Composition, age and provenance of organic matter in NW African dust over the Atlantic Ocean, Geochem. Geophys Geosyst., 3(8), 1050, doi:10.1029/2001GC000269, 2002.

Eichler, A., Schwikowski, M., Gäggeler, H.W., Furrer, V., Synal, H.-A., Beer, J., Sauer, M., and Funk, M.: Glaciochemical dating of an ice core from the upper Grenzgletscher (4200 $\mathrm{m}$ a.s.1.), J. Glaciol., 46, 507-515, 2000.

Groisman, P. Y., Karl, T. R., and Knight, R. W.: Observed impact of snow cover on the heat balance and the rise of continental spring temperatures, Science, 263, 198-200, 1993.

Hansen, J. E. and Sato, M.: Trends of measured climate forcing agents, PNAS, 98, 14 778-14 783, 2001.

Hansen, J. and Nazarenko, L.: Soot climate forcing via snow and ice albedos, Proceedings of the National Academy of Sciences, 101(2), 423-428, 2004.

Haywood, J. M., Roberts, D. L., Slingo, A., Edwards, J. M., and Shine, K. P.: General circulation model calculations of the direct radiative forcing by anthropogenic sulfate and fossil-fuel soot aerosol, J. Climate, 10, 1562-1577, 1997.

Holdsworth, G., Higuchi, K., Zielinski, G. A., Mayewski, P. A., Wahlen, M., Deck, B., Chylek, P., Johnson, B., and Damiano, P.: Historical biomass burning: Late $19^{\text {th }}$ century pioneer agriculture revolution in northern hemispheric ice core data and its atmospheric interpretation, J. Geophys. Res., 101, 23 317-23 334, 1996.

Hua, Q., Zoppi, U., Williams, A., and Smith, A.: Small-mass AMS radiocarbon analysis at ANTARES, Nucl. Instr. Meth. Phys. Res. B, 223, 284-292, doi:10.1016/j.nimb.2004.04.057, 2003.

Huber, T.: Bestimmung historischer Spurenstoffverläufe in alpinem Firn mittels kontinuierlicher Ionenchromatographischer Analyse, PhD Thesis, University of Bern, 2001.

Intergovernmental Panel on Climate Change (IPCC): Third Assessment Report, Climate Change 2001: The Scientific Basis, edited by: Houghton, J. T., Ding, Y., Griggs, D. J., et al., Cambridge Univ. Press, New York, 2001.

Jacobsen, M. C., Hansson, H.-C., Noone, K. J., and Charlson, R. J.: Organic atmospheric aerosols: review and state of the science, Rev. Geophys., 38(2), 267-294, 2000.

Jacobson, M. Z.: Control of fossil-fuel particulate carbon and organic matter. Possibly the most effective method of slowing global warming, J. Geophys. Res., 107(D19), 4410-4431, doi:10.1029/2001JD001376, 2002.

Jacobson, M. Z.: Climate response of fossil fuel and biofuel soot, accounting for soot's feedback to snow and sea ice albedo and emissivity, J. Geophys. Res., 109, D21201, doi:10.1029/2004JD004945, 2004.

Jenk, T. M., Szidat, S., Schwikowski, M., Gäggeler, H. W., Bolius, D., Wacker, L., Synal, H.-A., and Saurer, M.: Microgram level radiocarbon $\left({ }^{14} \mathrm{C}\right)$ determination on carbonaceous particles in ice, Nucl. Instr. Meth. Phys. Res. B, in press, 2006.

Junker, C. and Liousse, C.: A global emission inventory of carbonaceous aerosol from historic records of fossil fuel and biofuel consumption for the period 1860-1997, Atmos. Chem. Phys. Discuss., 6, 4897-4927, 2006,

http://www.atmos-chem-phys-discuss.net/6/4897/2006/.

Lavanchy, V. M. H., Gäggeler, H. W., Schotterer, U., Schwikowski, M., and Baltensperger, U.: Historical record of carbonaceous particle concentrations from a European high-alpine glacier (Colle Gnifetti, Switzerland), J. Geophys. Res., 104(D), 21227 $21236,1999 a$.

Lavanchy, V. M. H., Gäggeler, H. W., Nyeki, S., and Baltensperger, U.: Elemental carbon (EC) and black carbon (BC) measurements with a thermal method and an aethalometer at the high alpine research station Jungfraujoch, Atmos. Environ., 33, 2759-2769, 1999b.

Lemire, K. R., Allen, D. T., Klouda, G. A., and Lewis, C. W.: Fine particulate matter source attribution for Southeast Texas using ${ }^{14} \mathrm{C} /{ }^{13} \mathrm{C}$ ratios, J. Geophys. Res., 107, 4613-4619, 2002.

Levine, J. S., Cofer III, W. S., Sebacher, D. I., Rhinehart, R. P., Winstead, E. L., Sebacher, S., Hinkle, C. R., Schmaltzer, P. A., and Koller Jr, A. M.: The effects of fire on biogenic emissions of methane and nitric oxide from wetlands, J. Geophys. Res., 95, 1853-1864 1992.

Loh, A. I., Bauer J. E., and Druffel, R. M.: Variable ageing and storage of dissolved organic components in the open ocean, Nature, 430, 877-881, doi:10.1038/nature02780, 2004.

Novakov, T. and Penner, J. E.: Large contribution of organic aerosols to cloud-condensation-nuclei concentrations, Nature, 365, 823-826, 1993.

Pataki, D. E., Bowling, D. R., and Ehleringer, J. R.: Seasonal cycle of carbon dioxide and its isotopic composition in an urban atmosphere: Anthropogenic and biogenic effects, J. Geophys. Res., 108(D23), 473-4742, doi:10.1029/2003JD003865, 2003.

Penner, J. E., Eddlemann, H., and Novakov, T.: Towards the Devlopement of a global Inventory for Black Carbon Emissions, Atmos. Environ., 27A, 1277-1297, 1993.

Penner, J. E., Charlson, R. J., Hales, J. M., Laulainen, N. S., Leifer, R., Novakov, T., Ogren, J., Radke, L. F., Schwartz, S. E., and Travis, L.: Quantifying and minimizing uncertainty of climate forcing by anthropogenic aerosols, Bull. Am. Meteorol. Soc., 75, 375-400, 1994.

Petzold, A. and Niessner, R.: Method comparison study on sootselective techniques, Mikrochim. Acta, 117, 215-237, 1995.

Pfister, C.: Geschichte des Kantons Bern seit 1798, Bd. IV, Im Strom der Modernisierung. Bevölkerung, Wirtschaft und Umwelt 1700-1914, Historischer Verein, Bern, 1995.

Reddy, C. M., Pearson, A., Xu, L., McNichol, A. P., Benner Jr., B. A., Wise, S. A., Klouda, G. A., Currie, L. A., and Eglinton, T. I.: 
Radiocarbon as a tool to apportion the sources of polycyclic aromatic hydrocarbons and black carbon in environmental samples, Environ. Sci. Technol., 36, 1774-1782, 2002.

Reimer, P. J., Baillie, M. G. L., Bard, E., Bayliss, A., Beck, J. W., Bertrand, C., Blackwell, P. G., Buck, C. E., Burr, G., Cutler, K. B., Damon, P. E., Edwards, R. L., Fairbanks, R. G., Friedrich, M., Guilderson, T. P., Hughen, K. A., Kromer, B., McCormac, F. G., Manning, S., Bronk-Ramsey, C., van der Plicht, J., and Weyhenmeyer, C. E.: IntCal04 terrestrial radiocarbon age calibraion, 0-26 cal kyr BP, Radiocarbon, 46, 1029-1058, 2004.

Schotterer, U., Stichler, W., Graf, W., Gourcy, L., Huber, T., and Ginot, P.: Stable Isotopes in alpine ice cores: do they record climate variability?, Proc. Intern. Conf. on Isotope Techniques in the Study of Environmental Change, IAEA Vienna, 1998.

Schwerzmann, A., Funk, M., Blatter, H., Lüthi, M., Schwikowski, M., and Palmer, A.: A method to reconstruct past accumulation rates in alpine firn regions: A study on Fiescherhorn, Swiss Alps, J. Geophys. Res., 111, F01014, doi:10.1029/2005JF000283, 2006.

Schwikowski, M., Brütsch, S., Gäggeler, H. W., and Schotterer, U.: A high-resolution air chemistry record from an Alpine ice core: Fiescherhorn glacier, Swiss Alps, J. Geophys. Res., 104, 13709 13719, 1999a.

Schwikowski, M., Döscher, A., Gäggeler, H. W., and Schotterer, U.: Anthropogenic versus natural sources of atmospheric sulphate from an Alpine ice core, Tellus B , 51, 938-951, 1999 b.

Sharma, S., Lavoué, D., Cachier, H., Barrie, L. A., and Gong, S. L.: Long-term trends of the black carbon concentrations in the Canadian Arctic, J. Geophys. Res.-Atmos., 109, D15203, doi:10.1029/2003JD004331, 2004.

Slater, J. F., Currie, L. A., Dibb, J. E., and Benner Jr., B. A.: Distinguishing the relative contribution of fossil fuel and biomass combustion to aerosols deposited at Summit, Grenland through isotopic and molecular characterization of insoluble carbon, Atmos. Environ., 36, 4463-4477, 2002.

Stuiver, M. and Polach, H. A.: Discussion: Reporting of ${ }^{14} \mathrm{C}$ Data Radiocarbon, 19, 355-363, 1977.
Synal, H.-A., Jacob, S., and Suter, M.: The PSI/ETH small radiocarbon dating system, Nucl. Instr. Meth. Phys. Res. B, 172, 1-7, 2000.

Szidat, S., Jenk, T. M., Gäggeler, H. W., Synal, H.-A., Fisseha, R., Baltensperger, U., Kalberer, M., Samburova, V., Wacker, L., Saurer, M., Schwikowski, M., and Hajdas, I.: Source apportionment of Aerosols by ${ }^{14} \mathrm{C}$ measurements in different carbonaceous particle fractions, Radiocarbon, 46, 475-484, 2004a.

Szidat, S., Jenk, T. M., Gäggeler, H. W., Synal, H.-A., Fisseha, R., Baltensperger, U., Kalberer, M., Samburova, V., Reimann, S., Kasper-Giebl, A., and Hajdas, I.: Radiocarbon $\left({ }^{14} \mathrm{C}\right)$-deduced biogenic and anthropogenic contributions to organic carbon (OC) of urban aerosols from Zürich, Switzerland, Atmos. Environ., 38, 4035-4044, 2004b.

Szidat, S., Jenk, T. M., Gäggeler, H. W., Synal, H.-A., Hajdas, I., Bonani, G., and Saurer, M.: THEODORE, a two-step heating system for the EC/OC determination of radiocarbon $\left({ }^{14} \mathrm{C}\right)$ in the environment, Nucl. Instr. Meth. Phys. Res. B, 223-224, 829-836, 2004c.

Szidat, S., Jenk, T. M., Synal, H.-A., Kalberer, M., Wacker, L., Hajdas, I., Kasper-Giebl, A., and Baltensperger, U.: Contributions of fossil fuel, biomass burning, and biogenic emissions to carbonaceous aerosols in Zürich as traced by ${ }^{14} \mathrm{C}$, J. Geophys. Res., 111, D07206, doi:10.1029/2005JD0065902006, 2006.

Thompson, L. G., Davis, M. E., Mosley-Thompson, E., Sowers, T. A., Henderson, K. A., Zagorodnov, V. S., Lin, P.-N., Mikhalenko, V. N., Campen, R. K., Bolzan, J. F., Cole-Dai, J., Francou, B.: A 25 000-Year Tropical Climate History from Bolivian Ice Cores, Science, 282, 1858-1864, doi:10.1126/science.282.5395.1858, 1998.

Widory, D., Roy, S., LeMoullec, Y., Goupil, G., Cocherie, A., and Guerrot, C.: The origin of atmospheric particles in Paris: a view through carbon and lead isotopes, Atmos. Environ., 38, 953-961, 2004. 